\title{
Littoral-cell angioma of the spleen: A case report
}

\author{
Ángel Cosme, Ángel Tejada, Luis Bujanda, Manuel Vaquero, José Luis Elorza, Evelia Ojeda, Unai Goikoetxea
}

Ángel Cosme, Ángel Tejada, Luis Bujanda, Unai Goikoetxea, Department of Gastroenterology, Hospital Donostia, Spain Manuel Vaquero, Department of Pathology, Hospital Donostia, Spain

José Luis Elorza, Departamet of Surgery, Hospital Donostia, Spain

Evelia Ojeda, Department of Internal Medicine, Hospital Donostia, Spain

Correspondence to: Ángel Cosme, Department of Gastroenterology, Hospital Donostia, Paseo Beguiristain, s/n, 20014, San Sebastián (Gipuzkoa), Spain. acosme@chdo.osakidetza.net Telephone: +34-985-943003463 Fax: +34-985-943007065

Received: July 6, 2007

Revised: October 1, 2007

\begin{abstract}
Littoral-cell angioma (LCA) is a primary splenic vascular tumor that arises from the normal littoral cells lining the sinus channels of the splenic red pulp. We report a case of LCA of the spleen, which has been infrequently communicated in the literature. A 76-year-old man with a 2-wk history of weight loss, abdominal pain and changes in bowel habits was admitted to our hospital. Imaging studies (CT and MRI) showed multiple lesions in the spleen. Splenectomy was performed. Lining cells were positive for CD31/CD68 markers. Our case was associated with a serrated colonic adenoma. LCA is a benign vascular tumor of the spleen that needs to be included in the differential diagnosis of multiple splenic nodules.
\end{abstract}

(c) 2007 WJG. All rights reserved.

Key words: Littoral-cell angioma; Spleen

Cosme Á, Tejada Á, Bujanda L, Vaquero M, Elorza JL, Ojeda E, Goikoetxea U. Littoral-cell angioma of the spleen: A case report. World J Gastroenterol 2007; 13(48): 6603-6604

http://www.wjgnet.com/1007-9327/13/6603.asp

\section{INTRODUCTION}

Littoral-cell angioma (LCA) is a rare primary tumor of the spleen that was first described by Falk et al in $1991^{[1]}$. Considered a benign condition, this neoplasm arises from the red cell pulp sinuses and has intermediate features between those of endothelial and histiocytic cells. To the best of our knowledge, there have been 11 cases of LCA reported in the English-language literature since the description of this disease in $1991^{[2]}$. We report a case of LCA in a patient who had symptoms of weakness, pain and change in bowel habits. The combination of CT and MRI showed multiple lesions in the spleen. Postoperative pathology examination confirmed the final diagnosis of LCA.

\section{CASE REPORT}

A 76-year-old man was admitted to our hospital with a 2-wk history of weakness, weight loss, anorexia, hypogastric abdominal pain and change in bowel habits. His past medical history showed gastrectomy due to peptic ulcer at the age of 63 years and polypectomy of villous colonic adenoma 2 years before admission. Physical examination was normal. No splenomegaly was found. Results of routine laboratory tests were normal. Colonoscopy identified a polylobulated polyp $\geqslant 3 \mathrm{~cm}$ in size in the sigmoid colon, and polypectomy was performed. Pathology was conclusive for serrated adenoma. An enhanced CT scan of the abdomen showed multiple round, hypodense lesions in the spleen. Abdominal MRI revealed multiple splenic hypointensive lesions (Figure 1). Our presumptive preoperative diagnosis was lymphoma or hemangioma. Splenectomy was performed. Microscopically, lesions consisted of anastomosing vascular channels with papillary projections and cyst-like spaces. They were lined with endothelial cells that showed hemophagocytosis. Lining cells were positive for both vascular (CD31) and histiomonocytic (CD68) markers (Figure 2), but CD8 and CD3 were negative. Ten months after surgery, the patient was asymptomatic.

\section{DISCUSSION}

LCA of the spleen may occur at any age (1-77 years; median age, 50 years), with no sex-based predilection (female: male ratio, $5: 3)^{[2,3]}$. Clinically, patients have splenomegaly, abdominal pain, pyrexia of unknown origin $^{[4]}$ or hypersplenism. LCA may present as an incidental finding. LCA may appear as single or multiple lesions in the spleen. Splenic lesions ranged from 0.2 to $6.0 \mathrm{~cm}$. An extensive list of possibilities such as multiple hemangiomas, lymphoma, metastatic disease, and disseminated infections caused by fungi, mycobacteria, Pneumocystis carinii and sarcoidosis, should be considered in the differential diagnosis of multinodular splenomegaly. CT, MRI, US, and Tc99m RBC scan characteristics have been correlated with histological and immunohistochemical pathological features ${ }^{[5]}$. Consistent CT features of splenic LCA reported in the medical 


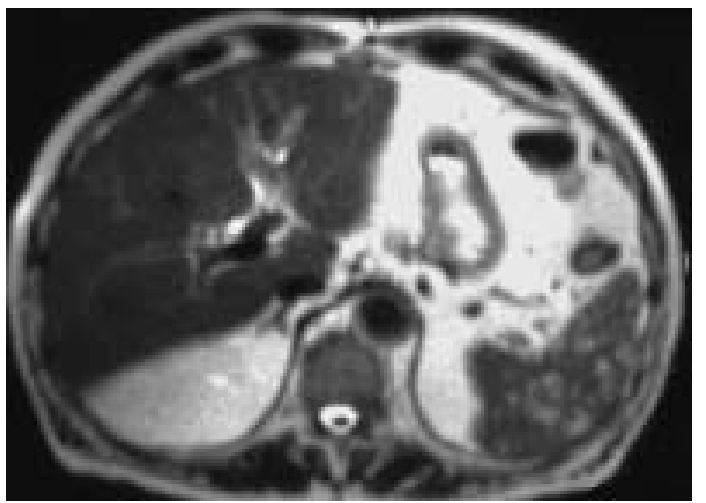

Figure $1 \mathrm{MRI}$ : multiple hypointense lesions in the spleen ( $\left.\mathrm{T}_{2}\right)$.

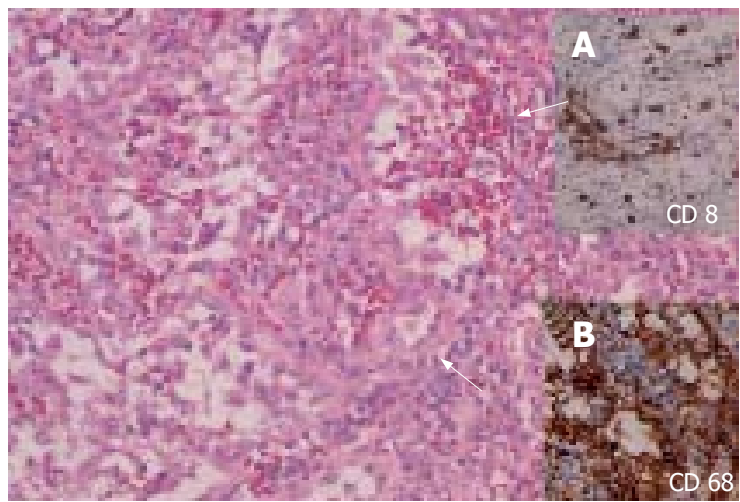

Figure 2 Vascular proliferation, well established (arrows), and very similar to normal spleen sinusoids. A: Negative for CD8; B: Positive for histiomonocytic markers.

literature include low-attenuating lesions on contrastenhanced images ${ }^{[2,6]}$. Morphological diagnosis is based on the presence of anastomosing vascular channels lined with tall endothelial cells, focal papillary fronds, and normal splenic sinuses at the periphery of the lesion. Combination of morphological and immunohistochemical analyses that show a hybrid endothelial-histiocitic phenotype establish the diagnosis of $\mathrm{LCA}^{[1,7]}$. Two case reports have described variants of LCA with histological features of malignancy ${ }^{[8,9]}$.

One third of the previously reported cases were associated with tumors of visceral organs, including colorectal, renal, hepatocellular ${ }^{[10]}$, lung ${ }^{[11]}$ and pancreatic adenocarcinomas, malignant lymphoma ${ }^{[12]}$, myelodysplastic syndrome ${ }^{[13]}$, or aplastic anaemia ${ }^{[14]}$. Since the malignant potential of LCA has not been firmly established in the literature, we recommend close clinical follow-up of patients with LCA of the spleen.

\section{REFERENCES}

1 Falk S, Stutte HJ, Frizzera G. Littoral cell angioma. A novel splenic vascular lesion demonstrating histiocytic differentiation. Am J Surg Pathol 1991; 15: 1023-1033

2 Levy AD, Abbott RM, Abbondanzo SL. Littoral cell angioma of the spleen: CT features with clinicopathologic comparison. Radiology 2004; 230: 485-490

3 Najera L, Dotor AM, Santoja C. Littoral cell angioma of the spleen. A case report and review of the literature. Rev Esp Patol 2006; 39: 49-53

4 Tan YM, Chuah KL, Wong WK. Littoral cell angioma of the spleen. Ann Acad Med Singapore 2004; 33: 524-526

5 Johnson C, Goyal M, Kim B, Wasdahl D, Nazinitsky K. Littoral cell angioma. Clin Imaging 2007; 31: 27-31

6 Goldfeld M, Cohen I, Loberant N, Mugrabi A, Katz I, Papura S, Noi I. Littoral cell angioma of the spleen: appearance on sonography and CT. J Clin Ultrasound 2002; 30: 510-513

7 Dascalescu CM, Wendum D, Gorin NC. Littoral-cell angioma as a cause of splenomegaly. $\mathrm{N}$ Engl J Med 2001; 345: 772-773

8 Rosso R, Paulli M, Gianelli U, Boveri E, Stella G, Magrini U. Littoral cell angiosarcoma of the spleen. Case report with immunohistochemical and ultrastructural analysis. Am J Surg Pathol 1995; 19: 1203-1208

9 Ben-Izhak O, Bejar J, Ben-Eliezer S, Vlodavsky E. Splenic littoral cell haemangioendothelioma: a new low-grade variant of malignant littoral cell tumour. Histopathology 2001; 39: 469-475

10 Lin CH, Yu JC, Shih ML, Peng YJ, Hsieh CB. Littoral cell angioma of the spleen in a patient with hepatocellular carcinoma. J Formos Med Assoc 2005; 104: 282-285

11 Collins GL, Morgan MB, Taylor FM 3rd. Littoral cell angiomatosis with poorly differentiated adenocarcinoma of the lung. Ann Diagn Pathol 2003; 7: 54-59

12 Bisceglia M, Sickel JZ, Giangaspero F, Gomes V, Amini M, Michal M. Littoral cell angioma of the spleen: an additional report of four cases with emphasis on the association with visceral organ cancers. Tumori 1998; 84: 595-599

13 Erçin C, Gürbüz Y, Hacihanefioğlu A, Turgut Karakaya A. Multiple littoral cell angioma of the spleen in a case of myelodysplastic syndrome. Hematology 2005; 10: 141-144

14 Tholouli E, Roulson JA, Byers R, Burton I, Liu Yin JA. Littoral cell angioma of the spleen in a patient with severe aplastic anaemia. Haematologica 2003; 88: ECR33

S- Editor Liu Y L- Editor Kerr C E- Editor Yin DH 